\title{
THE ASSOCIATION BETWEEN VITAMIN D STATUS AND CARDIOMETABOLIC DISORDERS IN OVERWEIGHT AND OBESE ADOLESCENTS
}

\author{
H. A. PAVLYSHYN, A.-M. A. SHULHAI \\ Department of Pediatrics № 2, I. Horbachevsky Ternopil National \\ Medical University, Ternopil, Ukraine; \\ 凹e-mail:shulhai_aa@tdmu.edu.ua
}

Received: 29 January 2021; Accepted: 23 April 2021

\begin{abstract}
An increase in the prevalence of overweight and obese adolescents is often combined with a low level of vitamin D that may be associated with lipid and carbohydrate metabolism disorders, which underlie the development of arterial hypertension and cardiometabolic changes. This work aimed to determine the association between vitamin $D$ status and the main parameters of lipid and carbohydrate metabolism, and anthropometric measurements. A total of 196 adolescents (129 boys and 67 girls) from the Ternopil region were examined. Their mean age was $15.5 \pm 2.3$ years. Based on the body mass index (BMI): 60 adolescents had normal body weight, 60 were overweight, and 76 were obese. Anthropometric measurements and general examinations were performed. In blood serum $25(\mathrm{OH}) \mathrm{D}$ levels and the main parameters of lipid and carbohydrate metabolism were determined. Low levels of $25(\mathrm{OH}) \mathrm{D}$ were found. Prevalence of vitamin D deficiency among adolescents with BMI up to the 85 th percentile was $56.7 \%$, with BMI in the $85-97^{\text {th }}$ percentiles was $70.0 \%$ and with BMI over the 97th percentile was $77.6 \%$. Serum $25(\mathrm{OH})$ D levels in overweight and obese adolescents had a significant correlation with BMI $(r=-0.427, P<0.001)$, waist circumference $(r=-0.462, P<0.001)$, highdensity lipoprotein cholesterol (HDL-C, $r=0.214, P=0.023$ ), low-density lipoprotein cholesterol ( $L D L-C$, $r=-0.226, P=0.011)$, atherogenic index $(r=-0.284, P=0.001)$, insulin level $(r=-0.483, P<0.001)$, and HOMA-IR index $(r=-0.454, P<0.001)$. We concluded that the development of cardiometabolic disorders in overweight and obese adolescents is associated with vitamin D status.
\end{abstract}

Keywords: level of vitamin D, adolescents, obesity, cardiometabolic disorders.

\section{Introduction}

Modern urbanized society is characterized by a rapidly increasing prevalence of overweight and obesity as well as vitamin D deficiency among children and adults [1-6]. Increasing overweight is associated with the development of cardiovascular and metabolic risk factors that are leading to circulatory system diseases, insulin resistance, and diabetes, which lead to impairment of life quality, promotion of early disability, and premature mortality $[1,7,8]$.

Currently, attention is drawn to the relationship between obesity and vitamin D deficiency, revealing the importance and understanding of their mutual effects and role in the development of cardiometabolic disorders among adolescents [9].
Peculiarities of the pleiotropic actions of vitamin D metabolites are the ability to influence the morphological state of cells through regulation of cell differentiation and apoptosis, and interact with membrane receptors, adaptor molecules, and nuclear coregulator proteins, as well as affect the functional state through the expression of receptors located in the nucleus [10-12].

Some of the main criteria for the diagnosis of cardiometabolic disorders in-clude lipid and carbohydrate metabolism disorders, which are combined with hyper-tension and abdominal obesity [13]. However, the association between cardiometa-bolic disorders in overweight and obese adolescents and vitamin D status has been insufficiently studied.

(C) 2021 Pavlyshyn H. A., Shulhai A.-M. A. This is an open-access article distributed under the terms of the Creative Commons Attribution License, which permits unrestricted use, distribution, and reproduction in any medium, provided the original author and source are credited. 
This work aimed to determine the association between vitamin D status and the main parameters of lipid and carbohydrate metabolism, and anthropometric measurements in adolescents with overweight and obesity.

\section{Materials and Methods}

The research was conducted at the Department of Pediatrics № 2, I. Horba-chevsky Ternopil National Medical University based on the communal institution of the Ternopil Regional Council "Ternopil Regional Children's Clinical Hospital”. The study was conducted according to the ethical standards in the Helsinki Declaration of 1975, as revised in 2008(5), as well as national law. The patient safety rules and the ethical standards and procedures for research on human beings (2000) were followed in carrying out the work. The Ethics Committee of the I. Horbachevsky Ternopil National Medical University approved the study on the $29^{\text {th }}$ of April 2020, session's protocol number 58 .

In all cases, informed consent was obtained from patients and their parents.

The inclusion criteria for the study were the following: age 12-17 years, body mass index (BMI) at or above the $85^{\text {th }}$ percentiles according to age-sex nomograms, written informed consent of parents and patients for the examination, and the No-vember-March, 2020 time period. The exclusion criteria were: obesity due to endo-crine diseases (hypercorticism, hypopituitarism, hypothyroidism, hypothalamic-pituitary injury), taking anticonvulsant drugs, glucocorticoids, or drugs that affect blood pressure, hereditary and congenital disorders, or diabetes mellitus.

A total of 196 adolescents (129 boys and 67 girls) from the Ternopil region were examined. Their mean age was $15.5 \pm 2.3$ years.

Anthropometric measurements were made and included: body weight (within the accuracy of $0.1 \mathrm{~kg}$ ), height (within the accuracy of $0.1 \mathrm{~cm}$ ), waist circumference (WC) and hip circumference (HC). Measurements were carried out with the use of generally accepted methods with the help of a floor weight scale, height meter, and flexible centimeter tape measure. WC was measured with the tape measure at the point midway between the iliac crest and the costal margin (lower rib). HC was measured at the level of the greatest protrusion of the buttocks. Next, the waist-hip ratio (WHR) was calculated as WC divided by HC. The waist-to-height ratio (WHtR) was defined as WC divided by height. BMI was calculated according to the formula (body weight $(\mathrm{kg}) /$ height $\left.^{2}\left(\mathrm{~m}^{2}\right)\right)$.

BMI was assessed by percentile curves for girls and boys separately. Over-weight was diagnosed in cases when BMI was greater than the $85^{\text {th }}$ to $97^{\text {th }}$ percentile, obesity when BMI exceeded the $97^{\text {th }}$ percentile, and normal body weight when BMI was less than the $85^{\text {th }}$ percentile, according to gender and age charts based on the World Health Organization (WHO) recommendations [14].

The blood pressure values were interpreted according to 2017 AAP Guidelines [15].

The results of anthropometric and blood pressure measurements are presented in Table 1.

Vitamin D status was determined according to the level of 25(OH)D (calcidiol) in blood serum by the immunoassay method with the use of the 25-OH Vitamin D ELISA test kit (EUROIMMUN, Lubeck, Germany) on the Multiskan FC analyzer (Thermo Scientific, Waltham, MA, USA), with an intra-assay coefficient of variation (CV) of 3.2-4.9\% and an inter-assay CV of $4.0-7.8 \%$.

The assessment of 25(OH)D levels was conducted according to the recommendations of the Endocrine Society Clinical Practice Guideline [16-19]. A calcidiol level of $30-100 \mathrm{ng} / \mathrm{mL}(76-250 \mathrm{nmol} / \mathrm{l})$ was considered as sufficient, vitamin D insufficiency was established for calcidiol in the range of 20-29 ng/ $(50-75 \mathrm{nmol} / \mathrm{l})$, vitamin $\mathrm{D}$ deficiency was determined at 25(OH)D levels below $20 \mathrm{ng} / \mathrm{ml}$ (less $50 \mathrm{nmol} / \mathrm{l}$ ) and vitamin D severe deficiency at 25(OH)D levels less than $10 \mathrm{ng} / \mathrm{ml}(25 \mathrm{nmol} / \mathrm{l})$. A level of $25(\mathrm{OH})$ D above $100 \mathrm{ng} / \mathrm{ml}$ (250 nmol/l) was considered as excessive [16, 17, 19].

To establish the association between vitamin $\mathrm{D}$ status and cardiometabolic factors, adolescents with overweight and obesity were divided into 4 subgroups, according to the level of calcidiol in blood serum.

To determine lipid metabolism, serum concentrations of total cholesterol (TC), high-density lipoprotein cholesterol (HDL-C) and triglycerides (TG) were measured by the enzymatic colorimetric method, using the Cholesterol Reagent and Cobas c111 automatic analyzer by Roche Diagnostics test systems (Rotkreuz, Switzerland). The low-density lipoprotein cholesterol (LDL-C) level was calculated by the Friedewald equation (LDL-C $=\mathrm{TC}-$ (TG/2.2+HDL-C). The very low-density lipoprotein cholesterol (VLDL-C) level was calculated as 
Ta b le 1. Anthropometric and blood pressure measurements in adolescents with normal body weight, overweight and obesity

\begin{tabular}{l|c|c|c}
\hline \multicolumn{1}{c|}{ Variables } & $\begin{array}{c}\text { Normal Body } \\
\text { Weight, }(n=60)\end{array}$ & Overweight, $(n=60)$ & Obese, $(n=76)$ \\
\hline Weight, kg & $62.50 \pm 10.21$ & $80.85 \pm 11.02$ & $98.59 \pm 12.36$ \\
Height, cm & $172.36 \pm 10.38$ & $176.51 \pm 10.16$ & $174.84 \pm 9.34$ \\
BMI, kg/m ${ }^{2}$ & $20.98 \pm 1.86$ & $25.83 \pm 1.54$ & $32.11 \pm 3.70$ \\
WC girls, cm & $68.75 \pm 3.73$ & $87.92 \pm 10.75$ & $110.63 \pm 18.13$ \\
WC boys, cm & $76.44 \pm 5.32$ & $91.23 \pm 7.30$ & $108.25 \pm 13.85$ \\
HC girls, cm & $88.81 \pm 4.59$ & $100.62 \pm 8.79$ & $115.79 \pm 13.46$ \\
HC boys, cm & $91.64 \pm 4.85$ & $103.91 \pm 8.13$ & $114.23 \pm 10.20$ \\
WHR girls & $0.78 \pm 0.06$ & $0.87 \pm 0.05$ & $0.95 \pm 0.06$ \\
WHR boys & $0.83 \pm 0.05$ & $0.88 \pm 0.04$ & $0.95 \pm 0.07$ \\
WHtR & $0.43 \pm 0.02$ & $0.52 \pm 0.02$ & $0.62 \pm 0.04$ \\
SBP, mm Hg & $108.87 \pm 10.05$ & $128.23 \pm 10.16$ & $136.05 \pm 11.54$ \\
DBP, mm Hg & $64.48 \pm 4.33$ & $81.15 \pm 8.23$ & $86.93 \pm 8.19$ \\
\hline
\end{tabular}

Note. Quantitative data are presented as mean (M) and standard deviation (SD). BMI - body mass index; WC - waist circumference, HC - hip circumference; WHR - ratio of waist circumference to hip circumference, WHtR - ratio of waist circumference to height; SBP - systolic blood pressure; DBP - diastolic blood pressure

VLDL-C $=\mathrm{TG} / 2.2$. Non-HDL-C was calculated as TC - HDL-C. The atherogenic index (AI) was calculated as follows: $\mathrm{AI}=(\mathrm{TC}-\mathrm{HDL}-\mathrm{C}) / \mathrm{HDL}-\mathrm{C}$ [20].

To determine carbohydrate metabolism, the blood glucose level, basal insulin level in the blood serum, and impaired glucose tolerance (IGT) were determined and the index of insulin resistance (homeostasis model assessment of insulin resistance, HOMA-IR) was calculated. An oral glucose tolerance test was performed to determine the level of fasting glucose and insulin in the blood and at $0,30,60,120$, and 180 min after glucose loading. Blood glucose levels were determined by the glucose oxidase method [21]. Blood insulin levels were measured by ELICA (immunochemical with electrochemiluminescent detection) using the Cobas 6000 analyzer and Roche Diagnostics test systems (Switzerland). The HOMA-IR index was calculated by the formula: HOMA-IR $=($ fasting glucose $\times$ fasting insulin)/22.5. Insulin resistance was detected at values of HOMA-IR that were 3.19 and higher. Impaired fasting glycemia (IFG) was defined as glucose levels from 5.6 to $6.9 \mathrm{mmol} / \mathrm{l}$ in fasting patients [21-22]. IGT was defined as fasting plasma glucose less than $7.0 \mathrm{mmol} / \mathrm{l}$ and as blood glucose level of $7.8 \mathrm{mmol} / \mathrm{l}$ or more but less than $11.1 \mathrm{mmol} / \mathrm{l}$ after a 2-hour oral glucose tolerance test (after ingestion of $1.75 \mathrm{~g} / \mathrm{kg}$ body weight, but not more than a $75 \mathrm{~g}$ oral glucose load) [21-22].

Statistical analysis was conducted using the Statistica 12.0 software package (StatSoft Inc., Inc. Tulsa, OK, USA). The assessment of the normality of the distribution of features in the variation series was carried out according to the Shapiro-Wilk criteria. Quantitative data were presented depending on the nature of the characteristics distribution. In the case of the normal distribution of features, the data were presented as the mean (M) and standard deviation (SD). In cases of non-normal distribution we calculated the median (Me), lower (Lq) and upper (Uq) quartiles.

Post hoc analysis between groups was performed using one-way analysis of variance (ANOVA) with Tukey's test. Comparisons of two independent samples with non-normal distributions of values were made using the nonparametric MannWhitney U-test. Statistical differences in qualitative features were determined using the chi-squared test $\left(\chi^{2}\right)$ with Yates correction. To evaluate possible associations be-tween 25(OH)D levels and variables of lipid metabolism, carbohydrate metabolism, and anthropometric measurements the Spearman correlation coefficients were determined. 
The significance of the differences between the values was considered signifi-cant at $P<0.05$.

\section{Results and Discussion}

The median serum 25(OH)D values in adolescents with normal body weight was 17.90 (12.1624.93) ng/ml, in overweight was 14.69 (10.27-20.30) $\mathrm{ng} / \mathrm{mL}$, and in obese adolescents was 12.71 (9.3617.37) $\mathrm{ng} / \mathrm{ml}$. Using the Mann-Whitney U-test, the mean values of serum 25(OH)D levels were significantly less in the over-weight adolescents than in those with normal body weight $(P=0.011)$, and in obese adolescents compared to those with normal body weight $(P<0.001)$.

The frequency of vitamin D sufficiency was 2.25 times lower in overweight adolescents and 3.79 times lower in obese adolescents than in adolescents with nor-mal body weight (Fig. 1).

The frequency of vitamin D deficiency in overweight adolescents increased by $23.52 \%\left(\chi^{2}=2.29\right.$; $P=0.130)$ and in obese adolescents by $36.99 \%$ $\left(\chi^{2}=5.88 ; P=0.010\right)$ compared to that in adolescents with normal body weight.

The results of this study have shown that the prevalence of vitamin D deficiency among adolescents was higher than among adolescents in Poland, where $17.1 \%$ of $25(\mathrm{OH}) \mathrm{D}$ values were within the normal range, $36.2 \%$ were insufficient, and as much as $46.7 \%$ showed vitamin D deficiency [23], and also more than among adolescents in Italy where vitamin D deficiency was determined in 32.3\% [24].
Overweight and obesity negatively affect the vitamin D status and the activity of vitamin D metabolites, and contribute to the development of vitamin D deficiency, which develops into more severe metabolic disease [25]. Accumulation of excessive adipose tissue in the body leads to the accumulation of inactive forms of vitamin D metabolites and decreases its bioavailability [26]. It has been established that vitamin D metabolism and 25(OH)D synthesis are impaired as a result of nonalcoholic hepatic steatosis formation in obesity [27].

The serum 25(OH)D levels in overweight and obese adolescents are character-ized by significant inverse correlations with the main anthropometric measurements (Table 2).

In obese children, vitamin $\mathrm{D}$ is sequestered in adipose tissue [28]. Adipose tissue expresses vitamin D receptors, and 1-alpha-hydroxylase converts $25(\mathrm{OH}) \mathrm{D}$ to calcitriol, and thus this tissue is a direct target for vitamin $\mathrm{D}$ and is a site of local synthesis of calcitriol [29]. At the same time, locally in adipose tissue vitamin D metabolites activity, it affect the differentiation of preadipocytes to mature adipocytes [30-31].

An increase in the amount of visceral fat is important in the development of cardiometabolic disorders, which can be determined by measuring the WC. In our study, 76 (75.2\%) adolescents with vitamin D deficiency and 13 (46.4\%) adolescents with vitamin D insufficiency had abdominal obesity (i.e., increased WC, WHR), and this was more than in

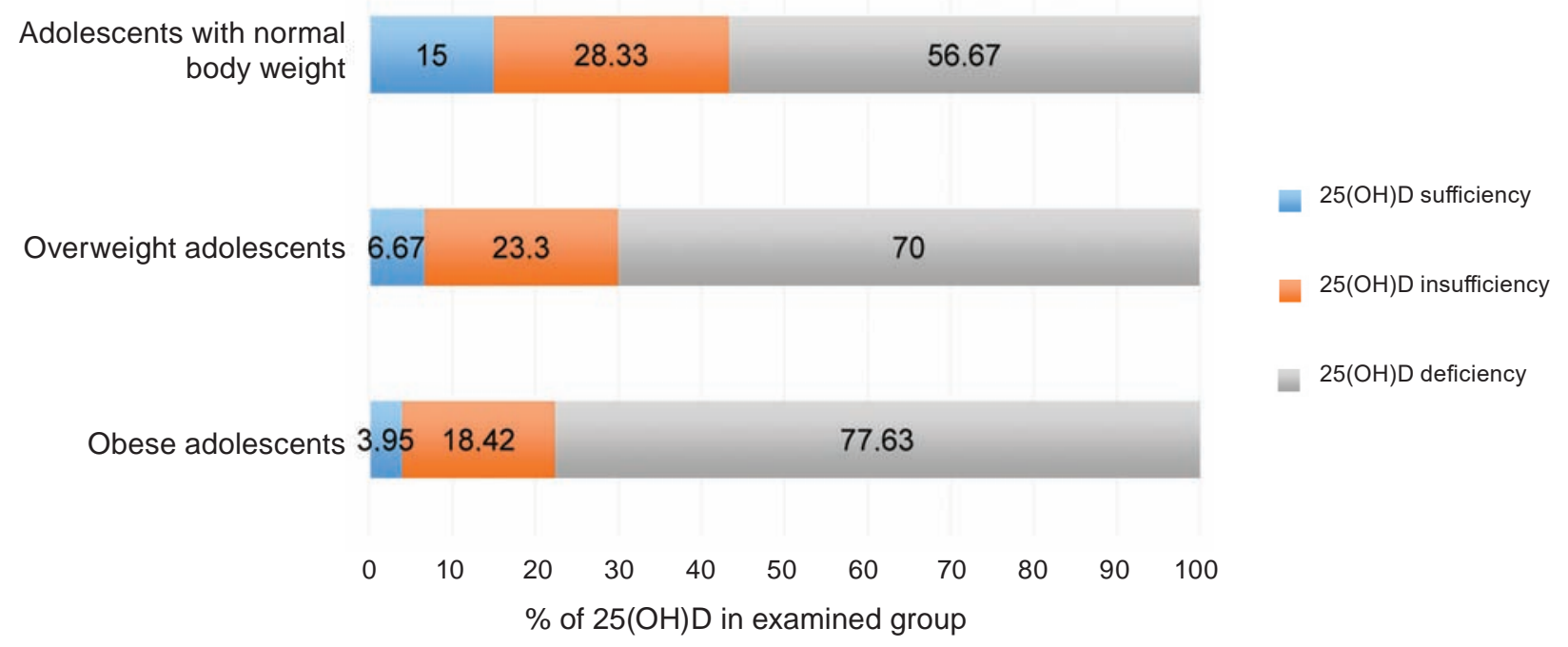

Fig. 1. Vitamin D $(25(\mathrm{OH}) \mathrm{D})$ levels in percentages of adolescents with normal body weight, overweight or obesity 
Table 2. Correlations between 25(OH)D levels and anthropometric measure-ments in overweight and obese adolescents $(n=136)$

\begin{tabular}{l|c|c}
\hline \multirow{2}{*}{ Variables } & \multicolumn{2}{|c}{ 25(OH)D level } \\
\cline { 2 - 3 } & $r$ & $P$-value \\
\hline BMI, $\mathrm{kg} / \mathrm{m}^{2}$ & -0.427 & 0.000 \\
Height, cm & 0.082 & 0.384 \\
WC, cm & -0.462 & 0.000 \\
HC, cm & -0.369 & 0.001 \\
WHR & -0.398 & 0.000 \\
WHtR & -0.406 & 0.000 \\
SBP, mm Hg & -0.278 & 0.014 \\
DBP, mm Hg & -0.102 & 0.096 \\
\hline
\end{tabular}

Note. Spearman correlations between the $25(\mathrm{OH}) \mathrm{D}$ levels and anthropometric measurements. BMI - body mass index; WC - waist circumference, HC - hip circumference; WHR - ratio of waist circumference to hip circumference, WHtR - ratio of waist circumference to height; SBP - systolic blood pressure; DBP - diastolic blood pressure vitamin D deficient adolescents in Iran, where only $13.8 \%$ had abdominal obesity [32].

With vitamin $\mathrm{D}$ deficiency the lipogenesis process is activated and lipolysis is suppressed, which leads to a growing amount of adipose tissue [28], development of adipocyte hypertrophy, atypical fat distribution, hypoxia, and chronic stress [33].

The associations between lipid metabolism variables and vitamin $\mathrm{D}$ status in overweight and obese adolescents have been determined (Table 3).

Researchers in Turkey have found an association between low 25(OH)D levels and impaired lipid profile, and in their study of adolescents with vitamin D deficiency $69.23 \%$ had dyslipidemia [34]. The frequencies of altered lipid metabolism variables in our study are shown in Fig. 2.

Generally, compared with adolescents who had sufficient vitamin D levels the levels of proatherogenic lipids (i.e., LDL-C, VLDL, non-HDL-C) were significantly increased in adolescents with vitamin $\mathrm{D}$ deficiency (subgroup 3) by $15.27 \%$ and in adolescents with severe vitamin D deficiency (subgroup 4) by $26.54 \%$.

Table 3. The characteristics of lipid metabolism in overweight and obese ado-lescents depending on the subgroup distribution of the $25(\mathrm{OH}) \mathrm{D}$ level

\begin{tabular}{|c|c|c|c|c|c|}
\hline Variables & $\begin{array}{c}25(\mathrm{OH}) \mathrm{D} \\
\geq 30 \mathrm{ng} / \mathrm{ml}, n=7, \\
\text { subgroup } 1\end{array}$ & $\begin{array}{l}25(\mathrm{OH}) \mathrm{D} 20- \\
29 \text { ng/ml, } n=28, \\
\text { subgroup } 2\end{array}$ & $\begin{array}{c}25(\mathrm{OH}) \mathrm{D} 10 \text { to } \\
<20 \mathrm{ng} / \mathrm{ml}, n=65, \\
\text { subgroup } 3\end{array}$ & $\begin{array}{c}25(\mathrm{OH}) \mathrm{D} \\
<10 \mathrm{ng} / \mathrm{ml}, n=36, \\
\text { subgroup } 4\end{array}$ & $\begin{array}{c}P \text {-value } \\
\text { (ANOVA) }\end{array}$ \\
\hline TC, mmol/l & $3.98 \pm 0.36^{\mathrm{b}}$ & $4.06 \pm 0.67$ & $4.43 \pm 0.58$ & $4.55 \pm 0.72^{\mathrm{b}}$ & 0.168 \\
\hline $\begin{array}{l}\text { HDL-C, } \\
\mathrm{mmol} / \mathrm{l}\end{array}$ & $1.22 \pm 0.16^{\mathrm{b}}$ & $1.27 \pm 0.21^{\mathrm{c}, \mathrm{d}}$ & $1.16 \pm 0.26^{\mathrm{c}, \mathrm{e}}$ & $1.03 \pm 0.29^{\mathrm{b}, \mathrm{d}, \mathrm{e}}$ & 0.032 \\
\hline $\begin{array}{l}\text { LDL-C, } \\
\mathrm{mmol} / \mathrm{l}\end{array}$ & $2.23 \pm 0.42^{\mathrm{a}, \mathrm{b}}$ & $2.37 \pm 0.38^{\mathrm{d}}$ & $2.65 \pm 0.73^{a}$ & $2.82 \pm 0.61^{\mathrm{b}, \mathrm{d}}$ & 0.041 \\
\hline $\begin{array}{l}\text { VLDL-C, } \\
\mathrm{mmol} / \mathrm{l}\end{array}$ & $0.60 \pm 0.12$ & $0.56 \pm 0.13^{\mathrm{d}}$ & $0.59 \pm 0.17^{e}$ & $0.67 \pm 0.21^{\mathrm{d}, \mathrm{e}}$ & 0.203 \\
\hline $\mathrm{TG}, \mathrm{mmol} / \mathrm{l}$ & $1.31 \pm 0.24$ & $1.21 \pm 0.30^{\mathrm{d}}$ & $1.30 \pm 0.38$ & $1.46 \pm 0.41^{\mathrm{d}}$ & 0.032 \\
\hline $\begin{array}{l}\text { non-HDL-C, } \\
\mathrm{mmol} / \mathrm{l}\end{array}$ & $2.43 \pm 0.81^{\mathrm{a}, \mathrm{b}}$ & $2.78 \pm 0.49^{d}$ & $3.25 \pm 0.52^{\mathrm{a}}$ & $3.48 \pm 0.67^{b, d}$ & 0.014 \\
\hline AI & $2.40 \pm 0.62^{\mathrm{a}, \mathrm{b}}$ & $2.26 \pm 0.58^{\mathrm{c}, \mathrm{d}}$ & $2.93 \pm 0.74^{\mathrm{a}, \mathrm{c}}$ & $3.49 \pm 0.88^{\mathrm{b}, \mathrm{d}}$ & 0.019 \\
\hline
\end{tabular}

Note. TC - total cholesterol; HDL-C - high-density lipoprotein cholesterol; LDL-C - low-density lipoprotein cholesterol; VLDL-C - very low-density lipoprotein cholesterol; TG - triglycerides; AI - atherogenic index. One-way ANOVA of vitamin D subgroups and of carbohydrate metabolism (Mean $\pm \mathrm{SD}$ ), $P$-value derived by ANOVA test. Post hoc multiple comparisons were made by using Tukey's test $(P<0.05)$ : a - the certainty of the difference between the indicators of subgroups 1 and $3 ; b$ - the certainty of the difference between the indicators of subgroups 1 and $4 ; c$ - the certainty of the difference between the indicators of subgroups 2 and $3 ; \mathrm{d}$ - the certainty of the difference between the indicators of subgroups 2 and $4 ; \mathrm{e}$ - the certainty of the difference between the indicators of subgroups 3 and 4 


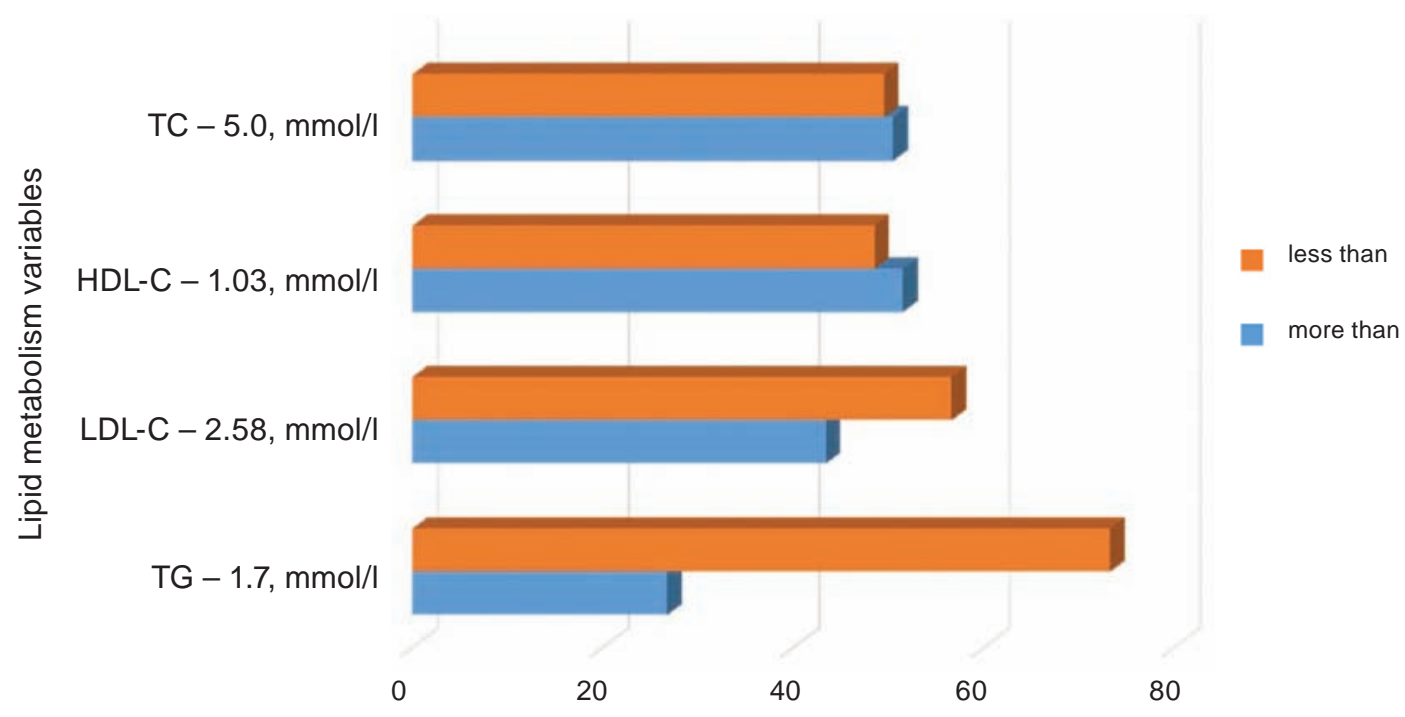

Percentages of lipid variables in adolescents with vitamin $D$ deficiency either less than or more than the indicated level of each variable (\%)

Fig. 2. The frequencies of altered lipid metabolism variables in adolescents with vitamin D deficiency. TC-total cholesterol; $H D L-C$ - high-density lipoprotein cholesterol; LDL-C-low-density lipoprotein cholesterol; $T G$-triglycerides

The associations between dyslipidemia and vitamin D levels were established by direct correlation between the 25(OH)D level and HDL-C and by inverse correla-tions between calcidiol and TC, LDLC, VLDL-C, TG, non-HDL-C, and AI (Table 4).

Increasing proatherogenic lipids that are associated with vitamin D deficiency contribute to increased cardiovascular risk [35]. It has been established that the effect of proatherogenic lipids is one of the important factors that contributes to developing hypertension [35]. The active vitamin D metabolite, calcitriol, through its effect on the reninangiotensin system is characterized by the ability to regulate blood pressure and to influence the functional state of endothelial cells, cardiomyocytes, and vascular smooth muscle cells [36].

Increased $\mathrm{SBP} \geq 130 \mathrm{~mm} \mathrm{Hg}$ and $\mathrm{DBP} \geq 85 \mathrm{~mm}$ $\mathrm{Hg}$ were in $48(81.3 \%)$ obese adolescents with vitamin D deficiency, and in 25 (59.5\%) overweight adolescents with vitamin D deficiency. Among all 101 adolescents with overweight or obesity and vitamin D deficiency, increased blood pressure was found in $73(72.3 \%)$ adolescents, consistent with an Italian study in which $60 \%$ had clinical hypertension [37].

There was a significant direct correlation between SBP and DBP and lipid metabolism variables, in particular with TC, LDL-C, TG, non-HDL-C,
Ta ble 4. Correlations between the 25(OH)D level and lipid metabolism varia-bles in overweight and obese adolescents $(n=136)$

\begin{tabular}{l|c|c}
\hline \multicolumn{1}{c|}{ Variables } & $r$ & $P$-value \\
\hline TC, mmol/l & -0.193 & 0.025 \\
HDL-C, mmol/l & 0.214 & 0.023 \\
LDL-C, mmol/l & -0.226 & 0.011 \\
VLDL-C, mmol/l & -0.125 & 0.146 \\
TG, mmol/l & -0.138 & 0.129 \\
non-HDL-C, mmol/l & -0.219 & 0.011 \\
AI & -0.284 & 0.001 \\
\hline
\end{tabular}

Note. Spearman correlations between 25(OH)D level and lipid metabolism variables. TC - total cholesterol; HDL-C - high-density lipoprotein cholesterol; LDLC - low-density lipoprotein cholesterol; VLDL-C - very low-density lipopro-tein cholesterol; TG - triglycerides; $\mathrm{AI}$ - atherogenic index

and AI. There were inverse correlations for SBP and DBP with HDL-C.

The next step was to study carbohydrate metabolism variables depending on the vitamin $\mathrm{D}$ level. IFG in overweight and obese adolescents was found in $14.29 \%$ with vitamin D insufficiency, and in $32.67 \%$ with vitamin D deficiency (Table 5). IGT in overweight and obese adolescents was found in 
Ta ble 5. The characteristics of carbohydrate metabolism variables in over-weight and obese adolescents depending on $25(\mathrm{OH}) \mathrm{D}$ levels

\begin{tabular}{l|c|c|c|c|c}
\hline \multicolumn{1}{|c|}{ Variables } & $\begin{array}{c}25(\mathrm{OH}) \mathrm{D} \\
\geq 30 \mathrm{ng} / \mathrm{ml}, n=7, \\
\text { subgroup 1 }\end{array}$ & $\begin{array}{c}25(\mathrm{OH}) \mathrm{D} 20- \\
29 \mathrm{ng} / \mathrm{ml}, n=28, \\
\text { subgroup 2 }\end{array}$ & $\begin{array}{c}25(\mathrm{OH}) \mathrm{D} 10 \text { to } \\
<20 \mathrm{ng} / \mathrm{ml}, n=65, \\
\text { subgroup 3 }\end{array}$ & $\begin{array}{c}25(\mathrm{OH}) \mathrm{D} \\
<10 \mathrm{ng} / \mathrm{ml}, n=36, \\
\text { subgroup 4 }\end{array}$ & $\begin{array}{c}P \text {-value } \\
\text { (ANOVA) }\end{array}$ \\
\hline $\begin{array}{l}\text { Blood glucose, } \\
\mathrm{mmol} / \mathrm{l}\end{array}$ & $4.79 \pm 0.43^{\mathrm{a}}$ & $5.35 \pm 0.41^{\mathrm{a}}$ & $5.34 \pm 0.61$ & $5.32 \pm 0.56$ & 0.145 \\
$\begin{array}{l}\text { Basal insulin, } \\
\mu \mathrm{O} / \mathrm{ml}\end{array}$ & $14.43 \pm 4.09^{\mathrm{b}, \mathrm{c}}$ & $14.98 \pm 4.72^{\mathrm{d}, \mathrm{e}}$ & $20.99 \pm 5.32^{\mathrm{b}, \mathrm{d}, \mathrm{f}}$ & $27.85 \pm 6.39^{\mathrm{c}, \mathrm{f}, \mathrm{f}}$ & 0.007 \\
HOMA-IR & $3.11 \pm 0.84^{\mathrm{b}, \mathrm{c}}$ & $3.62 \pm 1.03^{\mathrm{d}, \mathrm{e}}$ & $4.97 \pm 1.25^{\mathrm{b}, \mathrm{d}, \mathrm{f}}$ & $6.41 \pm 1.57^{\mathrm{c}, \mathrm{e}, \mathrm{f}}$ & 0.011 \\
IGT, n (\%) & - & $2(7.15)^{\mathrm{d}}$ & $6(9.23)^{\mathrm{d}}$ & $2(5.56)$ & 0.786 \\
IFG, n (\%) & $1(14.29)$ & $3(14.29)$ & $23(35.39)$ & $10(27.8)$ & 0.085 \\
\hline
\end{tabular}

Note. HOMA-IR -homeostasis model assessment of insulin resistance; IGT - impaired glucose tolerance; IFG - impaired fasting glycemia. One-way ANOVA of vitamin D subgroups and of carbohydrate metabolism (Mean $\pm \mathrm{SD}$ ), $P$-value derived by ANOVA test. Post hoc multiple comparisons were made by using Tukey's test $(P<0.05)$ : a - the cer-tainty of the difference between the indicators of subgroups 1 and $2 ; b$ - the certainty of the difference between the indicators of subgroups 1 and $3 ; \mathrm{c}$-the certainty of the difference between the indicators of subgroups 1 and $4 ; \mathrm{d}-$ the certainty of the difference between the indicators of subgroups 2 and 3; e - the certainty of the difference between the indicators of subgroups 2 and 4; $\mathrm{f}$ - the certainty of the difference between the indicators of subgroups 3 and 4

$7.15 \%$ with vitamin D insufficiency and in $7.92 \%$ with vitamin $\mathrm{D}$ deficiency. These findings confirm the results of other researchers [38]. There was no impaired glucose tolerance in adolescents with vitamin D sufficiency.

Hyperinsulinemia combined with vitamin D insufficiency was diagnosed in $7.15 \%$ of overweight and obese adolescents, and with vitamin D deficiency in $57.43 \%$. Compared to adolescents with vitamin D sufficiency, the insulin level in adolescents with 25(OH)D levels from 10 to $20 \mathrm{ng} / \mathrm{ml}$ was 1.45 times higher, and in those with 25(OH)D $<10 \mathrm{ng} / \mathrm{ml}$ was 1.91 times higher. Insulin resistance in adolescents with vitamin D insufficiency was found in $46.43 \%$, and with vitamin D deficiency in $82.18 \%$. There were significant correlations between $25(\mathrm{OH}) \mathrm{D}$ levels and the basal insulin level $(r=-0.483 ; P<0.001)$ and HOMA-IR $(r=-0.454 ; P<0.001)$ in overweight and obese adolescents, as determined by Spearman correlations. Our data confirm the results of studies by researchers in other countries concerning the correlations of serum 25(OH)D levels with insulin and HOMA-IR [39], but in our study, there was no correlation between 25(OH)D levels and blood glucose.

It is believed that vitamin $\mathrm{D}$ is associated with a positive effect on improving insulin secretion by pancreatic $\beta$-cells through nuclear vitamin D receptors, and also due to the calbindin effect on protein function through the regulation of intracellular cal- cium concentration [17, 40]. Vitamin D affects sensitivity of tissues and to insulin by stimulating the gene expression for insulin sensitivity, and through vitamin $\mathrm{D}$ receptors, which are in the cell nucleus [40-41].

Conclusions. Vitamin D deficiency is widespread among adolescents, especially with overweight and obesity. There is an association between vitamin $\mathrm{D}$ status and the main parameters of lipid metabolism, carbohydrate metabolism, and anthropometric measurements in adolescents with overweight and obesity. The severity of cardiometabolic disorders in overweight and obese adolescents has an association with the vitamin D status. Vitamin $\mathrm{D}$ deficiency in overweight and obese adolescents is associated with hypoalphalipoproteinemia, hypertension, increased proatherogenic lipids, hyperglycemia, insulinemia and insulin resistance, which are the main criteria for cardiometabolic disorders.

Conflict of interest. Authors have completed the Unified Conflicts of Interest form at http://ukrbiochemjournal.org/wp-content/uploads/2018/12/ coi_disclosure.pdf and declare no conflict of interest.

Funding. The study was supported by the Ministry of Health of Ukraine for I. Horbachevsky Ternopil National Medical University.

Acknowledgments. We thank Cedars-Sinai Medical Center's International Research and Inno- 
vation in Medicine Program, and the Association for Regional Cooperation in the Fields of Health, Science and Technology (RECOOP HST Association) for their support.

\section{ЗВ'ЯЗОК МІЖ РIВНЕМ ВITAМIHУ D ТА КАРДІОМЕТАБОЛІЧНИМИ ПОРУШЕННЯМИ В ПІДЛІТКІВ ІЗ НАДМІРНОЮ ВАГОЮ ТІЛА ТА ОЖИРІННЯМ}

\section{Г. А. Павлишин, А.-М. А. Шульгай凶}

Кафедра педіатрії № 2, Тернопільський національний медичний університет імені

I. Я. Горбачевського, Тернопіль, Україна; \e-mail: shulhai_aa@tdmu.edu.ua

Зростання кількості підлітків із надлишковою вагою та ожирінням часто поєднано 3 низьким рівнем в організмі вітаміну $\mathrm{D}$, що може призвести до порушень ліпідного та вуглеводного обмінів, які лежать в основі розвитку артеріальної гіпертензії та кардіометаболічних змін. Метою нашого дослідження було встановити взаємозв'язки між рівнем забезпеченості вітаміном D та основними показниками ліпідного, вуглеводного обмінів та антропометричних вимірювань. Обстежено 196 підлітків (129 хлопчиків та 67 дівчаток), які проживають у Тернопільській області. Середній вік дітей $15,5 \pm 2,3$ роки. Залежно від індексу маси тіла (BMI) дітей було розділено на три групи: 60 дітей підліткового віку з нормальною вагою тіла, 60 3 надлишковою та 76 - із ожирінням. Всім дітям проводили антропометричні вимірювання та загальноклінічні обстеження. У сироватці крові визначали рівень $25(\mathrm{OH}) \mathrm{D}$ та основні показники, що характеризують ліпідний і вуглеводний обмін. Встановлено, що у більшості дітей підліткового віку рівень 25(OH)D у сироватці крові був низьким. У підлітків із нормальною вагою дефіцит вітаміну D виявлено у $57,3 \%$, у підлітків з надлишковою вагою - у 70,72\%, а в дітей з ожирінням - у 77,2\%. За статистичної обробки рівень $25(\mathrm{OH}) \mathrm{D}$ у сироватці крові дітей 3 надмірною вагою та ожирінням вірогідно корелював із ВMI $(r=-0,427, P<0,001)$, ОТ $(r=-0,462$, $P<0,001)$, HDL-C $(r=0,214, P=0,023)$, LDL-C $(r=-0,226, P=0,011)$, IA $(\mathrm{r}=-0,284, \mathrm{P}=0,001)$, рівнем інсуліну $(r=-0,483, P<0,001)$, індексом інсулінорезистентності HOMA-IR $(r=-0,454$, $P<0,001)$. Зроблено висновок, що розвиток кардіометаболічних порушень у підлітків 3 надмірною вагою та ожирінням залежить від рівня забезпеченості вітаміном D.

Ключов і слова: рівень вітаміну D, підлітки, ожиріння, кардіометаболічні порушення

\section{References}

1. Wang Y, Lim H. The global childhood obesity epidemic and the association between socioeconomic status and childhood obesity. Int Rev Psychiatry. 2012; 24(3): 176-188.

2. Lartey ST, Magnussen CG, Si L, Boateng GO, de Graaff B, Biritwum RB, Minicuci N, Kowal P, Blizzard L, Palmer AJ. Rapidly increasing prevalence of overweight and obesity in older Ghanaian adults from 2007-2015: Evidence from WHO-SAGE Waves 1 \& 2. PLoS One. 2019; 14(8): e0215045.

3. Shulhai AMA, Pavlyshyn HA, Shulhai OM. Peculiarities of the prevalence and risk factors for vitamin D deficiency in overweight and obese adolescents in Ukraine. Arch Balk Med Union. 2019; 54(1): 57-63.

4. Holick MF. The vitamin D deficiency pandemic: Approaches for diagnosis, treatment and prevention. Rev Endocr Metab Disord. 2017; 18(2): 153-165.

5. Mata-Greenwood E, Huber HF, Li C , Nathanielsz PW. Role of pregnancy and obesity on vitamin D status, transport, and metabolism in baboon. Am $J$ Physiol Endocrinol Metab. 2019; 316(1): E63-E72.

6. Hingorani AD, Finan C, Schmidt AF. Obesity causes cardiovascular diseases: adding to the weight of evidence. Eur Heart J. 2020; 41(2): 227-230.

7. Akil L, Ahmad HA. Relationships between obesity and cardiovascular diseases in four southern states and Colorado. $J$ Health Care Poor Underserved. 2011; 22(4 Suppl): 61-72.

8. Shulhai AM, Pavlyshyn H, Shulhai O. Relation of carbohydrate exchange markers with vitamin D status in adolescents with overweight and obesity. Pediatr Endocrinol Diabetes Metab. 2019; 25(4): 169-176.

9. Atabek ME, Eklioglu BS, Akyürek N, Alp H. Association between vitamin D level and cardiovascular risk in obese children and adolescents. J Pediatr Endocrinol Metab. 2014; 27(7-8): 661-666. 
10. Bandera Merchan B, Morcillo S, Martin-Nuñez, Tinahones, FJ, Macías-González M. The role of vitamin D and VDR in carcinogenesis: Through epidemiology and basic sciences. J Steroid Biochem Mol Biol. 2017; 167: 203-218.

11. Abbas MA. Physiological functions of Vitamin D in adipose tissue. J Steroid Biochem Mol Biol. 2017; 165(Pt B): 369-381.

12. Bischoff-Ferrari HA. Relevance of vitamin D in muscle health. Rev Endocr Metab Disord. 2012; 13(1): 71-77.

13. Kirk EP, Klein S. Pathogenesis and pathophysiology of the cardiometabolic syndrome. J Clin Hypertens (Greenwich). 2009; 11(12): 761-765.

14. Childhood overweight and obesity. World Health Organization [Internet]. 2020. Available from: https://www.who.int/news-room/fact-sheets/ detail/obesity-and-overweight.

15. Flynn JT, Kaelber DC, Baker-Smith CM, Blowey D, Carroll AE, Daniels SR, de Ferranti SD, Dionne JM, Falkner B, Flinn SK, Gidding SS, Goodwin C, Leu MG, Powers ME, Rea C, Samuels J, Simasek M, Thaker VV, Urbina EM. Clinical practice guideline for screening and management of high blood pressure in children and adolescents. Pediatrics. 2017; 140(3): e20171904.

16. Holick MF, Binkley NC, Bischoff-Ferrari HA, Gordon CM, Hanley DA, Heaney RP, Murad MH, Weaver CM, Endocrine Society. Evaluation, treatment, and prevention of vitamin D deficiency: an Endocrine Society clinical practice guideline. J Clin Endocrinol Metab. 2011; 96(7): 1911-1930.

17. Povoroznyuk VV, Balatska NI. Vitamin D deficiency in the population of Ukraine and the risk factors for its development. Pain, Joints, Spine. 2012; (4.08): 5-11.

18. Pludowski P, Holick MF, Grant WB, Konstantynowicz J, Mascarenhas MR, Haq A, Povoroznyuk V, Balatska N, Barbosa AP, Karonova T, Rudenka E, Misiorowski W, Zakharova I, Rudenka A, Łukaszkiewicz J, Marcinowska-Suchowierska E, Łaszcz N, Abramowicz P, Bhattoa HP, Wimalawansa SJ. Vitamin D supplementation guidelines. J Steroid Biochem Mol Biol. 2018; 175: 125-135.

19. Płudowski P, Karczmarewicz E, Bayer M, Carter G, Chlebna-Sokół D, Czech-Kowalska J, Dębski R, Decsi T, Dobrzańska A, Franek E,
GłuszkoP, GrantWB,HolickMF, YankovskayaL, Konstantynowicz J, Książyk JB, KsiężopolskaOrłowska K, Lewiński A, Litwin M, Lohner S, Lorenc RS, Lukaszkiewicz J, MarcinowskaSuchowierska E, Milewicz A, Misiorowski W, Nowicki M, Povoroznyuk V, Piotr Rozentryt, Rudenka E, Shoenfeld Y, Socha P, Solnica B, Szalecki M, Tałałaj M, Varbiro S, Żmijewski MA. Practical guidelines for the supplementation of vitamin $\mathrm{D}$ and the treatment of deficits in Central Europe - recommended vitamin D intakes in the general population and groups at risk of vitamin D deficiency. Endokrynol Pol. 2013; 64(4): 319-327.

20. Jellinger PS, Handelsman $Y$, Rosenblit PD, Bloomgarden ZT, Fonseca VA, Garber AJ, Grunberger G, Guerin CK, Bell DSH, Mechanick JI, Pessah-Pollack R, Wyne K, Smith D, Brinton EA, Fazi S, Davidson M. American Association of Clinical Endocrinologists and American College of Endocrinology Guidelines for management of dyslipidemia and prevention of cardiovascular disease. Endocr Pract. 2017; 23(Suppl 2): 1-87.

21. Rao SS, Disraeli P, McGregor T. Impaired glucose tolerance and impaired fasting glucose. Am Fam Physician. 2004; 69(8): 1961-1968.

22. Sethuraman U, Zidan MA, Hanks L, Bagheri M, Ashraf A. Impact of vitamin D treatment on 25 hydroxy vitamin D levels and insulin homeostasis in obese African American adolescents in a randomized trial. $J$ Clin Transl Endocrinol. 2018; 12: 13-19.

23. Smyczyńska J, Smyczyńska U, Stawerska R, Domagalska-Nalewajek H, Lewiński A, Hilczer M. Seasonality of vitamin D concentrations and the incidence of vitamin D deficiency in children and adolescents from central Poland. Pediatr Endocrinol Diabetes Metab. 2019; 25(2): 54-59.

24. Vierucci F, Del Pistoia M, Fanos M, Erba P, Saggese G. Prevalence of hypovitaminosis D and predictors of vitamin D status in Italian healthy adolescents. Ital J Pediatr. 2014; 40: 54.

25. Peterson CA, Belenchia AM. Vitamin D deficiency \& childhood obesity: a tale of two epidemics. Mo Med. 2014; 111(1): 49-53.

26. Cheng L. The Convergence of Two Epidemics: Vitamin D Deficiency in Obese School-aged Children. J Pediatr Nurs. 2018; 38: 20-26. 
27. Nair S. Vitamin D deficiency and liver disease. Gastroenterol Hepatol (NY). 2010; 6(8): 491493.

28. Vanlint S. Vitamin D and obesity. Nutrients. 2013; 5(3): 949-956.

29. Gil Á, Plaza-Diaz J, Mesa MD. Vitamin D: Classic and Novel Actions. Ann Nutr Metab. 2018; 72(2): 87-95.

30. Sebo ZL, Rodeheffer MS. Assembling the adipose organ: adipocyte lineage segregation and adipogenesis in vivo. Development. 2019;146(7):dev172098.

31. Narvaez CJ, Simmons KM, Brunton J, Salinero A, Chittur SV, Welsh JE. Induction of STEAP4 correlates with 1,25-dihydroxyvitamin D3 stimulation of adipogenesis in mesenchymal progenitor cells derived from human adipose tissue. J Cell Physiol. 2013; 228(10): 2024-2036.

32. Jari M, Qorbani M, Moafi M, Motlagh ME, Keikha M, Ardalan G, Kelishadi R. Association of 25-hydroxy Vitamin D levels with indexes of general and abdominal obesity in Iranian adolescents: The CASPIAN-III study. J Res Med Sci. 2015; 20(2): 122-126.

33. Klöting N, Blüher M. Adipocyte dysfunction, inflammation and metabolic syndrome. Rev Endocr Metab Disord. 2014; 15(4): 277-287.

34. Erol M, Bostan Gayret Ö, Hamilçıkan Ş, Can E, Yiğit ÖL. Vitamin D deficiency and insulin resistance as risk factors for dyslipidemia in obese children. Arch Argent Pediatr. 2017; 115(2): 133-139.

35. Moore CE, Liu Y. Elevated systolic blood pressure of children in the United States is associated with low serum 25-hydroxyvitamin D concentrations related to body mass index: National Health and Examination Survey 20072010. Nutr Res. 2017; 38: 64-70.

36. McMullan CJ, Borgi L, Curhan GC, Fisher N, Forman JP. The effect of vitamin D on reninangiotensin system activation and blood pressure: a randomized control trial. J Hypertens. 2017; 35(4): 822-829.

37. Banzato C, Maffeis C, Maines E, Cavarzere $P$, Gaudino R, Fava C, Minuz P, Boner A, Antoniazzi F. Hypovitaminosis D and nocturnal hypertension in obese children: an interesting link. J Hum Hypertens. 2014; 28(6): 360-366.

38. Erdönmez D, Hatun, Çizmecioğlu FM, Keser A. No relationship between vitamin D status and insulin resistance in a group of high school students. J Clin Res Pediatr Endocrinol. 2011; 3(4): 198-201.

39. Durá-Travé T, Gallinas-Victoriano F, PeñafielFreire DM, Urretavizcaya-Martinez $M$, Moreno-González P, Chueca-Guindulain MJ. Hypovitaminosis D and cardiometabolic risk factors in adolescents with severe obesity. Children (Basel). 2020; 7(2): 10.

40. Szymczak-Pajor I, Śliwińska A. Analysis of Association between Vitamin D Deficiency and Insulin Resistance. Nutrients. 2019; 11(4): 794.

41. Maltsev SV, Mansurova GS. Metabolism of vitamin D and means of its main functions' implementation. Practical Med. 2014; 14(9): 1219. 